\title{
ディベート競技の論脈を検証する基本的手続き
}

\section{A Fundamental Procedure for Examining the Context of Arguments in Debate}

\author{
宇野 富美子 \\ Fumiko Uno

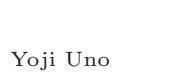 \\ 豊橋技術科学大学情報工学系 \\ Dept. of Information and Computer Seciences, Toyohasi University of Technology \\ uno@tutics.tut.ac.jp, http://www.system.tutics.tut.ac.jp/Members/uno.html
}

keywords: debate, argument, dialogue, proposition, context of argument

\section{Summary}

It is observed that the context of arguments sometimes deviates in debates and disputes. The subjects and predicates used in cross debates are similar but different between two opposing arguments. In this paper, we deal with debates and propose a fundamental procedure for examining the context of arguments. The procedure consists of two practical processes; one extracts constructive arguments and refutations (or replies), and the other examines the context between them. The procedure of examining the context is executed by the verification of words in the propositions of constructive arguments and refutations. The context between the propositions in which the verified words do not agree with each other is considered to be broken, and the proposition for the context is judged to be invalid.

\section{1.まえ がき}

対話処理において，少なくとも一般人や人文分野から 計算機に望まれるものは, 計算機との対話ということよ りも，次のような事柄であると思われる、『だらだらした 会議とか，なにを言っているのかわからないとか，弚う いう時，コンピュータ的チェックを……．光んなのは通 用しませんとか，だめですとか，もう一度いい直しなさ いとか, 弚んなのか欲しい』[寿岳 72] .この要求は未だ 全く満たされていない，我々が日頃接する討論，議論に おいて，口角泡を飛ばして喋られても一向にらちがあか ない樣は, 計算機による対話処理などによって何とかな らないものかと思わせられる .

討論や議論に関して, 次のような見解がある [坂井 71] . 『....... 「討論」や「推論」の内容は形式的演繹論理の乥れ とは異なり，実は, 語の定義や意味内容, 話題の脈絡 (コ ンテクスト) などを明瞭にさせることであったわけであ る．……略……ところで，もしこの「言葉の意味と用法 の整理」に関する一般的な方法が存在するとすれば，乥 れはまさに，日常言語の論理と称するにふさわしいもの である．しかし，このような一般的方法は明らかに存在 しない』これに対して本論文では, ディベート競技を取 り上げて，まさにこの゙一般的方法”を示す．すなわち， 対立する二つの論の間の論脈を抽出・検証するための基 本的な手続きを提案する.
論争支援への人工知能からのアプローチとして, 新田 は法的な論争に対する推論システムの研究を概説してい る[新田 98]．これらのシステムは, 非単調推論などを用 いて論争の形式化を行い, 論証の強弱を半順序関係で表 わすことによって，論証の信頼性 (優劣) を総合的に判 定する.これに対して，本論文では，論争の強弱などを 判定するのではなく, 討論や議論における脈絡を明瞭に することを目的とする，乥れ故，本論文で提案するのは， 推論システムではなく, ディベート競技における論争の 脈絡を抽出し, 脈が通っているか否かを検証する方法で ある

\section{2. ディベート 競技とは何か}

ディベートは，対話の一つであると見られる．対話シ ステムを総合的, 客観的, かつ定量的に評価するコンテ ストとして , 人工知能において「対話リーグ戦」(例えば， Dialeague97 [橋田 97]) が開催されている.これらの対 話リーグ戦では，2つの機械システム同士か評価のしや すい単純な課題 (例えば経路課題) に関して対話ゲーム を行う.これに対して，本論文でとりあげるディベート 競技では, 実際に人間同士が多樣で複雑な課題に関して 討論・論争を行う.

ディベート競技とは,「ひとつの論題に対し， 2 チーム の話し手が肯定する立場と否定する立場とに分かれ, 自 
分たちの議論の優位性を聞き手に理解してもらうことを 意図したうえで, 客観的な証拠資料に基いて議論をする コミュニケーション形態」と，ある解説書 [松本 96] は 定義している．ディベート競技の構成要素は, ディベー ター (肯定側および否定側) と審査員 (聴衆) と論題 (命 題) とから成っている.

紙面の都合上, 論脈検証のモデルとしてこれを選んだ が，著者はこのディベート競技の趣旨によく賛同するも のではない .ディベート競技の構成, 判定法などをもつ と明確にするべきである . 肝心な勝敗の為の判定の規準 があいまいで客観性に欠ける。例えば，審査員が 5 人い て, 3 人対 2 人で 3 人の方の組か勝ち, などという判定 の仕方では, 必ずしも正しい判定がされるとは限らない

ディベート競技の勝敗を決めるためには, 明確な判定 規準を設定する必要があり，論脈の検証は，これに対す る唯一の規準となると考えられる . 論脈を検証すること によって, 肯定側, 否定側, どちらの命題がよく論証さ れているかを判定することができる .

\section{3. ディベート 競技の論脈}

論脈は, 自然言語の中にある論 - 判断の脈絡 (コンテ クスト) であると定義される [ 宇野 91] . 換言すれば, 論 脈とは, 論の文章の文脈のことである.小説などにおけ るいわゆる文脈とは異なり, 論の文章の中を通される論 脈は, 文章の中にある論 - 判断谷れ自体の脈をより直接 的に見るものである

ディベート競技は肯定側，否定側の対話が順に交互に 行われ，立論と乥れに対する反論 (あるいは返答) から 成る.ディべート競技は，図１に示すように命題木によっ て表現することができる．最初に掲げられた論題は主命 題 Gであり，立論である. 論題である主命題 $\mathrm{G}$ が掲げ られたあと，弚れは多くの下位命題 $\mathrm{G}_{1}, \mathrm{G}_{2}, \cdots \cdots, \mathrm{G}_{n}$ に砕かれて対話は進められていく. 命題とは判断を言葉 で表わしたものである故, 単文が書かれることによって 命題が表現されるが, ディベート競技の中では対話が光 れに相当すると見なされる .

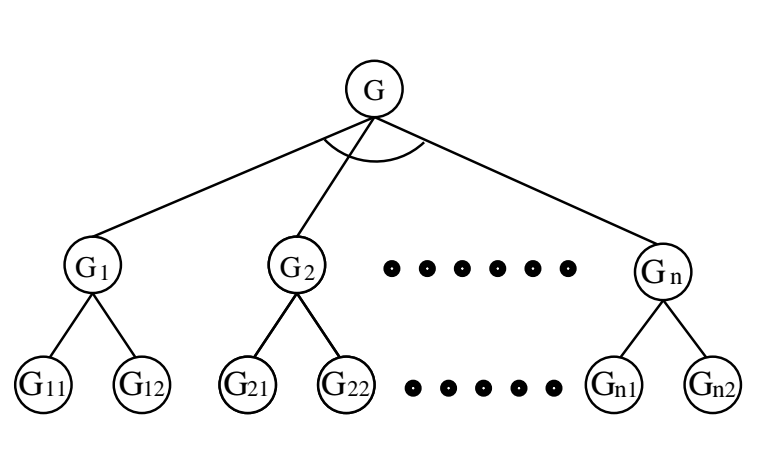

図 1 ディベート競技の対話文に表現されている命題木
論脈は命題と命題との間にある脈のことであり，ディ ベート競技の中では対話と対話との間にある.つまり，立 論と光れに対する反論・返答の間に論脈があると見なさ れる、論脈を検証する場合，立論は新しく論が立てられ るわけであるから，前の対話文との脈は原則的には見ら れない. 弚れに対する反論・返答との脈が見られるので あり，脈が正しく立論につながっているかどうかが検証 される.例えば図1において， $\mathrm{G}_{21}$ と $\mathrm{G}_{22}$ の間の脈は見 られるが， $\mathrm{G}_{12}$ と $\mathrm{G}_{21}$ の間の脈は見られない . 反論・返 答の命題が正しく立論の命題につながっていれば，反論・ 返答の命題は成立する．また，一つの対話文の中で, 単 文か幾つかあったり，複文になっていたりする場合には， 一対話文の中で文の間の脈が検証される .

多くの討論，論争は，論脈のズレの上に成り立ってい るのを見る．つまり，弚れが正されると，多くは討論光 のものが成り立たなくなるであろう .このズレにはある 法則がある．我々は無自覚のうちに乥の法則にしたがっ て論脈をズラして多くの討論，論争を行っている場合が 多い，光の法則とは何か，光れは次のようなものが考え られる。

I. 相手の論に対して光の述語を取り違えて答える (否 定する) ことである．多くは似て非なる述語が用い られる．否定するのであるから，述語の語尾 (活用 形) が一致しないのは当然であるが，語幹は同じで なければならない，述語の語幹が異なっては, 双方 の論の対応関係がずれてしまう .

II. 双方の論に同じ語がある場合，一方は弚の語に修 飾語をつけて論じ，他方はつけないで論じている場 合である．弚れでは異なる事柄について論じている ことになる．

すなわち, 乥こでは, 対する二つの論の間に，似て非 なる主語，述語が用いられる。主語においては，修飾語 の有無が問題になる. 述語においては, 弚の語幹が問題 になる．したがって，論脈を抽出する手続きも，このズ レの法則に則して脈を検証し，仕事を進めていくことに なる。

\section{4. 論脈検証の実行手続き}

ディベート競技の論脈を検証するには，対話文中にあ る立論および反論の抽出手続きと，両者の間にある脈の 検証手続きが必要である. 脈の検証手続きは, 立論・反 論における命題の語照合によって行われる. 語照合が一 致しない命題の間の脈は切れていることになり，弚の脈 による命題は成立しないことになる．

文は命題を表現するものである.討論，議論において 主語，述語が違う二つの対話は，別々の命題について論 じていることになるので, 語照合によって关れを検証す ることになる．

論脈検証の実行手続きは二つの段階から成り，段階 $\mathrm{A}$ 
が立論および反論の抽出の手続き，段階Bが谷の語照合 の手続きである．以下に段階 $A ， B$ の詳細を示す .

A：光の対話文が立論であるか反論であるかを検出する． (反論であれば立論との間の脈を見られなければなら ないからである・立論ならば原則的に言って关の必 要はない.) 弚れには，

a：最初の対話文は立論と見なされる。

$b$ : 立論の対話文の次の対話文は，

1. 弚の立論に対する反論 (あるいは返答) である.

2. 2文以上から成る対話文で, 兴の中に疑問文が あれば，光の立論に対する反論（あるいは返答） と，疑問文による立論と見なされる．

3.疑問文であれば立論と見なされる .

c：反論の対話文の次の対話文は立論と見なされる.

B：対話文の語照合を行う.

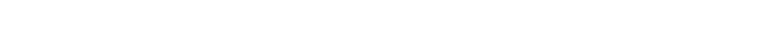
を行う．述語は光の語幹が照合される．すなわち， 語尾近くにある指定の助動詞の付く名詞, 動詞 , 形 容詞，形容動詞などの語幹か照合される．照合は 対象となる対話文同士の中の一文が一致すればよ いとされる．ただし，データベースには同義の述 語のリストがあり，照合された述語が同一の同義 述語リストにあれば，語幹が一致しなくても脈は 通っていると見なされる

$\mathrm{b}$ : 立論の対話文でも反論の対話文でも前対話文と同

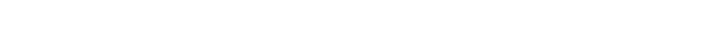
れる。

c：立論の対話文でも反論の対話文でも複数の文から 成ったり，複文である場合，前後の文に同じ語が ある時は, 弚れ光れの产の修飾語が照合される。 修飾語とは，文頭以降にあり，关の語のすぐ前に あって, 助詞「は」(主語につく)や「を」(客語に つく)で区切られていない名詞, 動詞, 形容詞を 指すこととする．ただし，修飾される語が，一連 の語句の他の語の修飾語となっている場合は, 光 の語の修飾語とは見られない.(一連の語句とは助 詞「と」,「の」でつながれた複数の単語のまとま りである.) 何れも照合一致しなければ脈は切れて いると見なされる

$d$ ：疑問詞が付く疑問文 (立論) と光の返答 (反論) に ついても，互いの述語の語幹か照合される．ただ し，立論の疑問詞に対応して返答に含まれるべき 特定の品詞が反論にあれば，述語の語幹が一致し なくても，脈は通っていると見なされる.例えば， 疑問詞「誰」に対しては人を表わす名詞があれば 脈は通っている . 尚，各疑問詞と対応する品詞と のすべての組み合わせがデータベースに登録され ているものとする .

e：「はい」,「いいえ」に該当する語による返事のみ
の反論の場合は, 語照合は要らない .

$f:$ 前対話文の脈が切れている場合は, 弚の対話文は 前対話文との脈を見なくてもよい(語照合は不要)。

上記の論脈検証手続きにおいて参照されるデータベー スには, 次のような知識が登録される.(1) 名詞, 動詞， 形容詞, 形容動詞, 副詞, 助詞, 助動詞, および述語の 同義語のリスト . (2) 疑問文検出のための接頭疑問詞 , 例 えば「何」,「どうして」「誰が」などの語のリスト，およ び接尾疑問詞，例えば「のか」,「なのか」などの語のリ スト，さらに各疑問詞と光れに対応する返答に含まれる べき特定の品詞との組み合わせのリスト. (3) 返事「は い」「いいえ」に該当する語: 例えば「关うだ」「关の通 りである」,「乥うではない」,「乥んなことはない」,「と んでもない」などの語のリストである . 尚 , リストの語 の数は競技において言い方を統一することで少なくする ことができる .

\section{5. 仕事遂行の例}

例題を掲げて，ディベート競技の論脈が，実行手続き によってどのようにして検証されるかを示す . 各対話文 の後の [ ] 内に，用いた実行手続きの該当する項目を記 す、脈のズレが検証された対話にはメ印をつけ，さらに， （）内に弚の理由を示すこととする．

【例題】[北岡 96]より

論題 :「日本人は働きすぎである」

肯定側：フランス人，否定側：二宮金次郎

フランス人 : 日本人は働きすぎだ .もつと休め . [A-a] 二宮金次郎：とんでもない，何を根拠に働きすぎという のだ · [A-b-2 \& B-e]

フランス人 : 労働時間が長いからである . [A-b-1 \& B-d] 二宮金次郎：労働時間が長いことを働きすぎだというの か. [A-c \& B-b]

フランス人 : 乥うだ . [A-b-1 \& B-e]

二宮金次郎：具体的にいうと，何時間なのだ . [A-c]

フランス人：日本人の労働時間は欧米人と比較して長い

んだ、概算でいうと，日本人は約年間 2000 時間，ド イツ人は 1600 時間，フランス人は 1700 時間，アメ リカやイギリスは 1800 時間だ . 先進国と比較して労 働時間が長い . だから働きすぎなのである . [A-b-1 $\&$ B-c, B-d]

二宮金次郎：労働時間の統計比較は乥の通りだ .しかし ぞれがどうしたのだ. 単に労働時間が長いという数 字を提示しているだけだ .すなわち, 労働時間が長 いだけでどうして働きすぎといえるのかね . 働きす ぎとは労働時間の長さをいうのか. 弚んなことは誰 が決めたのかね. [A-c \& B-b] X (立論であるが前 対話文に同じ語「労働時間」,「労働時間が長い」， 
「働きすぎ」があるので光れぞれの修飾語を照合する と，「労働時間」の場合，前対話文には「日本人の」 と「比較して」という修飾語があるのに当対話文に は修飾語が無く, 脈はこの箇所て切れているとみな される.)

フランス人 : 労働時間が長いということは働きすぎとい うことである.当然の常識でないのか. [A-b-2 \& B-f] 二宮金次郎：いや，弚う断定はできない，私などは朝か ら夜が暗くなるまで, 一日中，一年中ほとんど休み なしに働いているが，働きすぎだとは思わない . 労 働時間が長くても働きすぎだとは思ったこともない . 日本の昔の人はみんな働きすぎなどと思ったことも ないよ . まだ , 働きが足りないくらいだ . 朝は朝星， 夜は夜星という諺があるくらいだ . 朝の暗いうちか ら働いて夜暗くなるまで働いたものである.これが 日本の伝統だ . [A-b-1 \& B-a] × (反論であるから 前対話文である立論のものと述語照合を行うと, 述 語の語幹がす心゙て一致せず , 脈はこの箇所で切れて いることになる .)

フランス人：しかし，日本人は働きすぎだと言われてい る.働きすぎだから，製品が洪水のようにヨーロッ パに流れこむのである. [A-c \& B-f]

二宮金次郎：働きすぎと製品とは関係ない．製品が優秀 だから多くの人が買うのである . [A-b-1 \& B-a]× (前対話文のものと述語照合を行うと述語の語幹が すべて一致せず，脈はこの箇所で切れていることに なる.)

フランス人：いや，過剩な製品か輸出されるのだ . 日本 は国内を閉鎖的にしておいてヨーロッパにもってく るのではないのか . [A-c \& B-f]

二宮金次郎：「すべてが光うではない，経済の需要と供 給の原則が㗢いているのである.需要があるのだ.だ から，日本の製品が売れるのである. 悪い製品なら 売れない. [A-b-1 \& B-a] × (前対話文のものと述 語照合を行うと，述語の語幹がすべて一致せず，脈 はこの箇所で切れていることになる .

後略

論脈の検証によって，例題の競技においては，二宮金 次郎による否定側の論脈が 4箇所切れているので, 論脈 が切れていないフランス人による肯定側の勝ちである .

尚，蓋然的に言って，論脈のズレはディベートのどち らか一方の側に偏るものなので, 多くの場合こうした勝 敗の判定が可能であると考えられる .

\section{6. あと がき}

従来の論争支援に関する多くの研究では, 対立する論 証の優劣を判定することが目的であり，弚れ光れの論拠 の信頼性や強弱を順序付けるために, 複雑な推論システ
ムや論理プログラミングなどを必要とする [新田 98] . ま た，場合によってはあいまいな価值基準を階層構造とし て,あらかじめ準備しておくことも要求される.これに 対して本論文は, 対話と対話との間にある論理的な筋道 を明確にすることを目的として，論脈という新しい概念 を導入した。対話 (論) を命題に対応させると，論脈は 命題と命題との間の論理的な関係と見なせる . 命題とは 「判断を言葉で表わしたもの」であり，論脈は言葉で表わ された判断の脈であるから，推論などを一切用いること なく，自然言語処理によって，これを見い出すことがで きる、さらに, 論脈がズレる場合には，3章で述べたよ うな法則性があるので, 表層的な情報のみに基づいて論 脈を検証することが可能である．また乥れ故に，論脈と いう概念は, 従来の対話研究における整合性や一貫性の 概念よりも形式化が容易であると思われる .

人工知能の対話処理においては, より厳密でより汎用 性の高い実行手続きが求められるのは言うまでもない . しかし本研究においては, 手続きの厳密性ということよ りも，まず多くの討論・論争における根本的な問題点，す なわち論脈のズレの存在を指摘し, 論脈を抽出・検証す るための基本的な手続きを示すことに主眼をおいた。論 脈の検証手続きのポイントは, 立論と反論における命題 間の語照合であり，論脈にズレがあると語照合が一致し ないのである.これによって，似て非なる主語・述語が 用いられる場合の論脈のズレを見い出すことができる .

5 章では，比較的短いディベート競技への適用例を示 したが, すべての場合のディベート競技に適用するには， 本研究で提案した論脈抽出の手続きをさらに発展させて， 詳細なアルゴリズムを作成しなければならない，特に論 脈のズレ方については，3章で示した論脈のズレの法則 の他にもいくつか考えられ，光れらも手続きの項目に加 える必要がある . 実用化にはデータベースの構築が不可 欠であり，樣々な対話に応じて，同義語を適切に選択し てリストを作成したり，疑問詞と光の返答にある品詞と の対応関係を詳細に検討しなければならない .これらは 今後の研究課題としたい.

尚，一つの対話か時間にして何分も続くような長いディ ベートに対しては，文を抄録して命題を端的に表示する ことによって , 効率よく論脈の検証ができる .

\section{$\diamond$ 参 考 文 献 $\diamond$}

[橋田 97] 橋田浩一, 伝康晴, 長尾確, 柏岡秀紀, 酒井桂一, 島 津明, 中野幹男: Dialeague - 自然言語処理システムの総合評 価 -, 人工知能学会誌, Vol. 12, No. 3, pp. 390-399 (1997).

[寿岳 72] 寿岳章子, 沢田允茂, 高須正郎, 野崎昭弘 : コンピュー タとことば, 言語生活 $10, \mathrm{pp}$. 2-11 (1972).

[北岡 96] 北岡俊明:ディベート, 明日香出版社, pp. 78-83 (1996). [松本 96] 松本茂:頭を鍛えるディベート入門, 講談社 , pp. 20-21 (1996).

[新田 98] 新田克己：法律における事例べース推論と論争 , 人工 知能学会誌, Vol. 13, No. 2, pp. 181-188 (1998).

[坂井 71] 坂井秀樹, 坂本百大: 現代論理学, 東海大学出版会, pp. 27 (1971). 
[宇野 91] 宇野富美子, 宇野洋二: 脳の思考機能理解と論脈理解, 人工知能学会全国大会 (第 5 回) 論文集, pp. 247-250 (1991)

〔担当委員 : 山本秀樹〕

2000 年 3 月 15 日 受理

著者 紹介

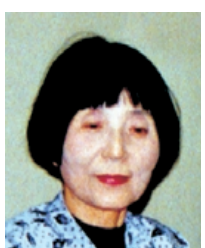

\section{宇野 富美子(正会員)}

1943 年一宮高等女学校卒業 .評論, 論説, エッセイの論 脈理解や脳の記憶メカニズムなどに興味を持つ。

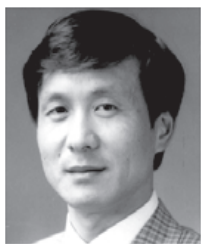

宇野 洋二

1978 年名古屋大学大学院工学研究科修士課程修了. 1988 年大阪大学大学院基礎工学研究科博士課程修了. 工学博 $士$. 同年東京大学工学部・計数工学科助手, 1991 年同講 師. 1992 年 ATR 人間情報通信研究所主任研究員を経て, 1996 年より豊橋技術科学大学情報工学系教授. 生体の運 動制御, 脳の計算理論の研究に従事. 日本神経回路学会理 事, 計測自動制御学会, 電子情報通信学会各会員。 